\title{
Investigação Criminal nos Tribunais SUPERIORES
}

Márcio Adriano Anselmo

\section{INTRODUÇÃo}

\author{
O tema do foro privilegiado tem sido alvo de discussão \\ nos últimos tempos, sobretudo em razão do grande volume de \\ investigações criminais submetidas a tramitação perante o Su- \\ premo Tribunal Federal e sua ineficiência ${ }^{2}$, já reconhecida inclu- \\ sive por integrantes do Tribunal.
}

1 Delegado de Polícia Federal. Doutor em Direito (USP).Professor da Pós-Graduação da Escola Superior de Polícia

2 Conforme aponta Danielle Cavalcanti, "Pesquisa divulgada pela Associação dos Magistrados do Brasil, no ano de 2007, revelou um diagnóstico da situação dos processos relativos aos detentores de foro por prerrogativa de função no Supremo Tribunal Federal e no Superior Tribunal de Justiça, tribunais estes submetidos a volumoso trabalho decorrente dos milhares de processos e procedimentos que, anualmente, são distribuídos a cada um de seus integrantes. Observou-se que, de 15 de dezembro de 1988 a 15 de junho de 2007, foram distribuídas 130 (cento e trinta) ações penais no STF, das quais apenas 6 (seis) tiveram julgamento do seu mérito por aquele tribunal, redundando em absolvição dos acusados/querelados. Os de mais processos ainda estavam em tramitação ou haviam sido arquivados por causas diversas (entre elas a extinção da punibilidade decorrente da prescrição, o decurso da suspensão condicional do processo ou a perempção), ou remetidos a tribunal ou instância inferior.

No STJ, foram distribuídas 483 (quatrocentas e oitenta e três) ações penais entre 23 de maio de 1989 e 6 de junho de 2007, sendo que apenas 16 (dezesseis) haviam sido objeto de julgamento por aquela Corte, redundando em 11 (onze) absolvições e 5 (cinco) condenações. Os demais processos ainda estavam em tramitação, ou se encontravam arquivados por causas diversas (entre elas a extinção da punibilidade decorrente da prescrição, o decurso da suspensão condicional do processo ou a perempção), ou remetidos a outro tribunal ou instância, ou estavam aguardando autorização legislativa para processamento." (CAVALCANTI, Danielle Souza de Andrade e Silva. A investigação preliminar nos delitos de competência originária de tribunais. Rio de Janeiro: Lumen Juris, 2011, p. 6). 
Por óbvio, a fase de investigação criminal (ou investigação preliminar), entendida aqui como o iter que vai do recebimento da notícia do fato supostamente criminoso até a decisão do titular da ação penal quanto ao oferecimento de denúncia ou arquivamento, embora tida como administrativa, trata-se de fase de fundamental importância, tendo em vista a profusão de material probatório que é produzida nessa fase que, apesar das críticas, são os elementos que, após o devido contraditório judicial, embasam as devidas sentenças condenatórias.

Ao tratar da investigação preliminar nos delitos de competência originária de tribunais, Danielle Cavalcanti ${ }^{3}$ aponta quatro fatores que justificam o seu estudo: um, a inexistência de regras procedimentais no direito positivo na regência do tema; dois, a recorrente incidências de casos de inquéritos autuados nos tribunais superiores; três, a escassa literatura específica sobre o tema; e quatro, a perspectiva da eficiência da persecução penal desses crimes, cada vez mais colocada em xeque.

\section{O ESTAdo dA ARTE do PROBLEMA}

A investigação criminal busca verificar empiricamente se um sujeito cometeu determinado delito, que, conforme aponta Luigi Ferrajoli ${ }^{4}$, deve ser anteriormente estabelecido por lei com exatidão, de forma a identificar quais seriam esses fatos empíricos a serem considerados como delitos.

Nesse caminho, resta a passagem pela compreensão normativa do tipo como caminho indispensável que deve percorrer a autoridade policial no percurso da investigação criminal, uma

3 CAVALCANTI, Danielle Souza de Andrade e Silva. A investigação preliminar nos delitos de competência originária de tribunais. Rio de Janeiro: Lumen Juris, 2011, p. 4-7.

4 FERRAJOLI, Luigi. Direito e Razão: Teoria do Garantismo Penal. São Paulo: RT, 2002, p. 38 . 
vez que esta deve ter por objetivo - a partir de elementos primeiros que a subsidiaram e que apontam a prática de um crime, por meio da investigação criminal -, buscar tornar claros os limites da infração cometida e os elementos de autoria.

Eliomar da Silva Pereira ${ }^{5}$ constrói sua definição de investigação criminal como uma

pesquisa, ou conjunto de pesquisas, administrada estrategicamente, que, tendo por base critérios de verdade e métodos limitados juridicamente por direitos e garantias fundamentais, está dirigida a obter provas acerca da existência de um crime, bem como indícios de sua autoria, tendo por fim justificar um processo penal, ou sua não instauração, se for o caso, tudo instrumentalizado sob uma forma jurídica estabelecida por lei.

Deve o Delegado de Polícia, no curso da investigação criminal, pautar-se pelos conhecimentos angariados pela teoria do crime, que, ainda segundo o mesmo autor, "cumpre uma função operativa, em virtude de seu caráter metodológico, ao fazer a mediação entre o fato punível (como objeto da realidade) e o tipo penal (como hipótese legal normativa)" ${ }^{\prime 6}$. Conforme argumenta André Nicollit, "o Delegado de Polícia é o primeiro a fazer um juízo de tipicidade da conduta." 7

O inquérito policial é o instrumento, no direito processual penal pátrio, que legalmente materializa a investigação criminal, presidida pela autoridade policial, nos termos do artigo $4^{\circ}$ do Código de Processo Penal. Consiste numa fase anterior ao processo penal propriamente dito, destinada a subsidiar o início

5 PEREIRA, Eliomar da Silva. Teoria da Investigação Criminal - uma introdução jurídico-científica. Coimbra: Almedina, 2010, p. 86-87.

6 Op. Cit., p. 229.

7 NICOLLIT , Andre Luiz. Manual de Processo Penal. 3를 Ed. São Paulo: Elsevier, 2012, p. 86 . 
deste, atuando como um filtro, para, segundo Lopes $\mathrm{Jr}^{8}$ (2013, p. 280), "purificar, aperfeiçoar, conhecer o certo". Por ora, nos ocuparemos da relação entre teoria das provas e inquérito policial. Usando-se a perspectiva de Alexandre Morais da Rosa ${ }^{9}$, podemos, sem dúvida, compreender também a fase pré-processual como um jogo, marcado pela estratégia e tática dele decorrentes. Assim, não se pode desconsiderar a fase da investigação preliminar, conforme o presente artigo se propõe.

Embora seja recorrente na doutrina a expressão de que não se produz prova no inquérito policial, tal expressão apresenta-se falaciosa, uma vez que a quase totalidade dos elementos probatórios carreados às ações penais são identificados ou produzidos no curso da investigação criminal na fase pré-processual, ou seja, no curso do inquérito. Conforme destaca Danielle Cavalcanti ${ }^{10}$ :

A investigação preliminar é assunto crucial ao estudo do processo penal, na medida em que permite a reunião de elementos que justifiquem a instauração ou não da persecução judicial, além de impedir a formulação de acusações açodadas, exercendo assim relevantes funções preventiva e preparatória do processo.

Preliminarmente, é possível apontar aqui duas situações distintas de tramitação de investigação em tribunais superiores: inicialmente, as investigações interna corporis (como por exemplo a investigação de autoridades judiciárias, previstas no art. 33, § único da LOMAN ou no artigo 41, § único da LOMP - cuja redação é idêntica $)^{11}$; no segundo caso, refere-se à investigação

8 LOPES JR. Aury. Direito Processual Penal. 10ª ed. São Paulo: Saraiva, 2012, p. 280.

9 ROSA, Alexandre Morais da. Guia Compacto de Processo Penal conforme a Teoria dos Jogos. Florianópolis: Empório do Direito, 2015.

10 CAVALCANTI, Danielle Souza de Andrade e Silva. A investigação preliminar nos delitos de competência originária de tribunais. Rio de Janeiro: Lumen Juris, 2011, p. 279.

11 “Quando, no curso de investigação, houver indício da prática de crime por parte do 
criminal de crimes que envolvam autoridades com prerrogativa de foro em razão da função, notadamente agentes políticos.

Nossa Constituição Federal, a título exemplificativo, atribui, no artigo 102, ao STF a prerrogativa de processar e julgar originariamente (grifo nosso):

b) nas infrações penais comuns, o Presidente da República, o Vice-Presidente, os membros do Congresso Nacional, seus próprios Ministros e o Procurador-Geral da República;

c) nas infrações penais comuns e nos crimes de responsabilidade, os Ministros de Estado e os Comandantes da Marinha, do Exército e da Aeronáutica, ressalvado o disposto no art. 52, I, os membros dos Tribunais Superiores, os do Tribunal de Contas da União e os chefes de missão diplomática de caráter permanente

Observa-se que, somente nesses dois incisos temos um universo superior a seiscentas autoridades com prerrogativa de foro perante a Suprema corte. Ao tratar do tema recentemente, o Ministro Luís Roberto Barroso ${ }^{12}$, que já havia criticado anteriormente a situação ${ }^{13}$, foi enfático ao consignar que:

O foro por prerrogativa de função, apelidado de foro privilegiado, é um mal para o Supremo Tribunal Federal e para o país. É preciso acabar com ele ou reservá-lo a um número mínimo de autoridades, como os chefes de Poder. Há três ordens de razões que justificam sua eliminação ou redução drástica:

Razões filosóficas: trata-se de uma reminiscência aristocrática, não republicana, que dá privilégio a alguns, sem um fundamento razoável;

magistrado, a autoridade policial, civil ou militar, remeterá os respectivos autos ao Tribunal ou órgão especial competente para o julgamento, a fim de que prossiga na investigação."

12 BARROSO, Luis Roberto. Foro privilegiado deve acabar ou ser limitado aos chefes dos Poderes. Disponível em http://www.conjur.com.br/2016-mai-23/roberto-barrosoforo-privilegiado-acabar-reduzir-impunidade. Acesso em 27 abr. 2016.

13 BARROSO, Luis Roberto. Ministro Barroso diz que foro privilegiado é "desastre para o país". Disponível em http://www.conjur.com.br/2016-mar-31/ministro-barrosoforo-privilegiado-desastre-pais. Acesso em 30 abr. 2016. 
Razões estruturais: Cortes constitucionais, como o STF, não foram concebidas para funcionarem como juízos criminais de $1^{o}$ grau, nem têm estrutura para isso. O julgamento da AP 470 ocupou o tribunal por um ano e meio, em 69 sessões;

Razões de justiça: o foro por prerrogativa é causa frequente de impunidade, porque é demorado e permite a manipulação da jurisdição do Tribunal."

Na mesma oportunidade, foram apontados dados estatísticos que apontam o seguinte cenário:

- (i) tramitam no STF, atualmente, 369 inquéritos e 102 ações penais contra parlamentares;

- (ii) o prazo médio para recebimento de uma denúncia pelo STF é de 617 dias (um juiz de $1^{\circ}$ grau recebe, como regra, em menos de uma semana, porque o procedimento é muito mais simples); e

- (iii) desde que o STF começou a julgar efetivamente ações penais (a partir da EC 35/2001, que deixou de condicionar ações contra parlamentares à autorização da casa legislativa), já ocorreram 59 casos de prescrição, entre inquéritos e ações penais.

Segundo estudo do próprio STF ${ }^{14}$, somente em 2010 deram-se os primeiros casos de condenação por parte do órgão.

Outras estatísticas que retratam a situação de modo mais aprofundado podem ainda ser encontradas no estudo realizado pela Associação dos Magistrados Brasileiros ${ }^{15}$, onde o quadro se apresenta ainda mais alarmante. Danielle Cavalcanti ${ }^{16}$ ainda agrega que:

14 Conforme notícia disponível em <http://stf.jus.br/portal/cms/verNoticiaDetalhe. asp?idConteudo=101385> . Acesso em 20 dez. 2016.

15 ASSOCIAÇÃO DOS MAGISTRADOS BRASILEIROS. Juízes contra a corrupção. Diagnóstico do problema da impunidade e possíveis soluções propostas pela AMB. Disponível em http://www.amb.com.br/portal/docs/noticias/estudo_corrupcao.pdf. Acesso em 27 abr. 2016.

16 Op. Cit., p. 279. 
As dificuldades são potencializadas se direcionamos nosso foco às investigações preliminares nos delitos de competência originária de tribunais, cuja importância é sobressalente no sistema criminal, por representarem a persecução do Estado contra seus próprios agentes, aqueles que ditam muitas vezes os rumos da política, da segurança e da economia do país, com reflexo em toda a sociedade.

Observa-se portanto a relevância do tema, seja na perspectiva da carência de estudos que busquem sistematizar o tratamento dessas investigações preliminares, seja ainda na busca de alcançar maior eficiência nessas investigações, que, em última análise, colocam em risco o Estado democrático de direito, por estimularem uma casta de privilegiados que permanecem fora de alcance da persecução criminal.

\section{A inVestigação CRiminal nOS inquéritos de COMPETÊNCIA ORIGINÁRIA DOS TRIBUNAIS}

O Código de Processo Penal, no art. 1º, caput, define, como regra, sua incidência ao processo penal em todo o território brasileiro, trazendo algumas exceções. Vejamos:

Art. $1^{0}$ O processo penal reger-se-á, em todo o território brasileiro, por este Código, ressalvados:

[...]

IV - os processos da competência do tribunal especial (Constituição, art. 122, no 17);

[...]

Parágrafo único. Aplicar-se-á, entretanto, este Código aos processos referidos nos nos. IV e $V$, quando as leis especiais que os regulam não dispuserem de modo diverso.

Em regra, as normas do Código de Processo Penal não poderiam ser aplicadas aos inquéritos originários, conforme a 
excepcionalidade criada no inciso IV. Contudo, sua aplicabilidade é autorizada, por imposição do parágrafo único, no caso de ausência de tratamento diverso das leis especiais.

No caso de inquéritos que tramitam no Supremo Tribunal Federal e Superior Tribunal de Justiça, as normas especiais existentes são a Lei no 8.038/90 e os respectivos regimentos internos do STF (RISTF) e do STJ (RISTJ), ambos tratam de forma mínima a temática. A Lei n 8.658/93, por sua vez, estendeu a aplicação das normas do diploma anterior às ações penais de competência originária dos Tribunais de Justiça dos Estados e do Distrito Federal, e dos Tribunais Regionais Federais.

Deveras, a Lei no 8.038/90, que institui normas procedimentais para os processos de ação originária perante o Superior Tribunal de Justiça e o Supremo Tribunal Federal, apesar de ter tratado da ação penal originária, instituindo nuances específicas na tramitação processual, nada discorreu sobre os inquéritos que envolvessem investigados com prerrogativa de foro:

TÍTULO I

Processos de Competência Originária

CAPÍTULO I

Ação Penal Originária

Art. $1^{\circ}$ - Nos crimes de ação penal pública, o Ministério Público terá o prazo de quinze dias para oferecer denúncia ou pedir arquivamento do inquérito ou das peças informativas.

$\S 1^{0}$ - Diligências complementares poderão ser deferidas pelo relator, com interrupção do prazo deste artigo.

$\S 2^{\circ}$ - Se o indiciado estiver preso:

a) o prazo para oferecimento da denúncia será de cinco dias;

b) as diligências complementares não interromperão o prazo, salvo se o relator, ao deferi-las, determinar o relaxamento da prisão. 
Art. $2^{2}$ - O relator, escolhido na forma regimental, será o juiz da instrução, que se realizará segundo o disposto neste capítulo, no Código de Processo Penal, no que for aplicável, e no Regimento Interno do Tribunal.

Parágrafo único - O relator terá as atribuições que a legislação processual confere aos juízes singulares.

Art. $3^{\circ}$ - Compete ao relator:

I - determinar o arquivamento do inquérito ou de peças informativas, quando o requerer o Ministério Público, ou submeter o requerimento à decisão competente do Tribunal;

II - decretar a extinção da punibilidade, nos casos previstos em lei.

III - convocar desembargadores de Turmas Criminais dos Tribunais de Justiça ou dos Tribunais Regionais Federais, bem como juizes de varas criminais da Justiça dos Estados e da Justiça Federal, pelo prazo de 6 (seis) meses, prorrogável por igual período, até o máximo de 2 (dois) anos, para a realização do interrogatório e de outros atos da instrução, na sede do tribunal ou no local onde se deva produzir o ato.

O Regimento Interno do Supremo Tribunal Federal, vigente durante o advento da Constituição Federal de 1988, por sua vez, também não abordou a temática. Contudo, no ano de 2011, foram editadas emendas regimentais, inserindo algumas regras para a fase pré-processual. Vejamos:

Art. 230-C. Instaurado o inquérito, a autoridade policial deverá em sessenta dias reunir os elementos necessários à conclusão das investigações, efetuando as inquirições e realizando as demais diligências necessárias à elucidação dos fatos, apresentando, ao final, peça informativa.

$\S 1^{0}$ O Relator poderá deferir a prorrogação do prazo sob requerimento fundamentado da autoridade policial ou do Procurador-Geral da República, que deverão indicar as diligências que faltam ser concluídas.

$\S 2^{\underline{o}}$ Os requerimentos de prisão, busca e apreensão, quebra de 
sigilo telefônico, bancário, fiscal, e telemático, interceptação telefônica, além de outras medidas invasivas, serão processados e apreciados, em autos apartados e sob sigilo, pelo Relator.

Art. 231. Apresentada a peça informativa pela autoridade policial, o Relator encaminhará os autos ao Procurador-Geral da República, que terá quinze dias para oferecer a denúncia ou requerer o arquivamento.

$\S 1^{0}$ As diligências complementares ao inquérito podem ser requeridas pelo Procurador-Geral ao Relator, interrompendo o prazo deste artigo, se deferidas.

$\S 2^{\circ}$ As diligências complementares não interrompem o prazo para oferecimento de denúncia, se o indiciado estiver preso.

$\S 3^{\underline{o}} \mathrm{Na}$ hipótese do parágrafo anterior, se as diligências forem indispensáveis ao oferecimento da denúncia, o Relator determinará o relaxamento da prisão do indiciado; se não o forem, mandará, depois de oferecida a denúncia, que se realizem em separado, sem prejuízo da prisão e do processo.

$\S 4^{0}$ O Relator tem competência para determinar o arquivamento, quando o requerer o Procurador-Geral da República ou quando verificar:

a) a existência manifesta de causa excludente da ilicitude do fato;

b) a existência manifesta de causa excludente da culpabilidade do agente, salvo inimputabilidade;

c) que o fato narrado evidentemente não constitui crime;

d) extinta a punibilidade do agente; ou

e) ausência de indícios mínimos de autoria ou materialidade, nos casos em que forem descumpridos os prazos para a instrução do inquérito ou para oferecimento de denúncia.

$\S 5^{01}$ Se o indiciado estiver preso, o prazo a que se refere o caput será de cinco dias.

$\S 6^{0} \mathrm{O}$ inquérito arquivado por falta de indícios mínimos de autoria ou materialidade poderá ser reaberto, caso surjam novos elementos. 
Constata-se que a única regra do RISTF que colide frontalmente com as normas do CPP seria o prazo para conclusão das investigações. No Código de Processo são exigidos 30 (trinta) dias; enquanto, na seara regimental, 60 (sessenta) dias. Na parte restante, não se identifica qualquer outro confronto entre ambos os corpos normativos.

O RISTJ, da mesma forma, ao tratar da Ação Penal Originária, pouco dispõe sobre a fase de investigação preliminar:

Art. 217. Nos crimes de ação penal pública, o Ministério Público terá o prazo de quinze dias para oferecer denúncia ou pedir arquivamento do inquérito ou das peças informativas.

$\S 1^{\circ}$ Diligências complementares poderão ser deferidas pelo relator, com interrupção do prazo deste artigo.

$\S 2$ o Se o indiciado estiver preso:

a) o prazo para oferecimento da denúncia será de cinco dias;

b) as diligências complementares não interromperão o prazo, salvo se o relator, ao deferi-las, determinar o relaxamento da prisão.

Art. 218. O relator será o juiz da instrução, que se realizará segundo o disposto neste capítulo, no Código de Processo Penal, no que for aplicável, e neste Regimento Interno. Parágrafo único. O relator terá as atribuições que a legislação penal confere aos juízes singulares, podendo submeter diretamente à decisão do órgão colegiado competente as questões surgidas durante a instrução. (Redação dada pela Emenda Regimental n. 2, de 1992)

Art. 219. Competirá ao relator:

I - determinar o arquivamento do inquérito ou das peças informativas, quando o requerer o Ministério Público, ou submeter o requerimento à decisão da Corte Especial;

II - decretar a extinção da punibilidade nos casos previstos em lei. 
Assim, observa-se que a fase de investigação preliminar não é regida pelo RISTF ou RISTJ, de modo que devem ser aplicadas às disposições do CPP.

Inicialmente, cabe aqui destacar que a Constituição Federal é clara no sentido da atribuição dos tribunais para processar e julgar. Nada fala sobre investigar. Assim, não cabe aqui interpretação extensiva. Desse modo, nos parece absolutamente desarrazoada a forma como essa fase de investigação preliminar vem sendo interpretada na atualidade, com excesso de poderes na figura do relator que, para além de atuar nas situações sujeitas a reserva de jurisdição, tem lhe sido atribuídas verdadeiras funções de juiz-investigador, cabendo a este até mesmo deferir ou não diligências a serem cumpridas pela polícia judiciária, a quem compete constitucionalmente a investigação criminal.

Nesse sentido, imperioso aqui mencionar trecho da ementa da ADI 1.570/DF, relatada pelo Min. Maurício Corrêa, acerca da Lei n 9.034/95: “3. Funções de investigador e inquisidor. Atribuições conferidas ao Ministério Público e às Polícias Federal e Civil (CF, art. 129, I e VIII e $\S 2^{\circ}$; e 144, $\S 1^{\circ}$, I e IV, e $\S 4^{\circ}$. A realização de inquérito é função que a Constituição reserva à polícia."

\section{Do INDICIAMENTO NA INVESTIGAÇÃo PERANTE OS TRIBUNAIS SUPERIORES}

Um dos problemas mais latentes no cenário da investigação preliminar de autoridades com prerrogativa de foro trata-se do ato de indiciamento, que deve ser compatibilizado com o modelo acusatório de persecução penal adotado pela Constituição Federal, com a tendência jurisprudencial da Suprema Corte de trazer para a fase investigatória garantias e direitos decorrentes do princípio do contraditório e da ampla defesa e com a Lei no ${ }^{-12.830 / 2013 . ~}$ 
Cabe destacar, preliminarmente, que a figura do indiciamento passou a ter tratamento legislativo somente com a entrada em vigor da Lei $\mathrm{n}^{\mathrm{o}}$ 12.830/2013 . Em momento pretérito, inexistia descrição normativa sobre este modelo jurídico, apesar de figurarem, por décadas, em diversos corpos legais, a expressão "indiciado". Não obstante a omissão legislativa, a doutrina e jurisprudência já haviam traçado os contornos do instituto, tendo a lei apenas consolidado um posicionamento já adotado pela maioria dos intérpretes do Direito. Nesse passo, a inovação legislativa estabeleceu que "o indiciamento, privativo do delegado de polícia, dar-se-á por ato fundamentado, mediante análise técnico-jurídica do fato, que deverá indicar a autoria, materialidade e suas circunstâncias."

O instituto é intrínseco e exclusivo da fase de investigação criminal, sendo a formalização do juízo de convencimento da autoridade policial. Nesse sentido, foi a manifestação em artigo jurídico já publicado:

$O$ ato de indiciamento é o ato do Delegado de Polícia, enquanto presidente da investigação, via de regra praticado ao término da mesma, ao considerar concluída a fase de coleta de elementos probatórios do delito investigado, quando é possível concluir-se pela autoria de determinado crime, individualizando-se o autor. ${ }^{17}$

Enquanto o juízo de convicção do Delegado de Polícia sobre a prática delitiva se externaliza por meio do indiciamento, o convencimento do Ministério Público é retratado pela apresentação de denúncia e o posicionamento do magistrado é evidenciado quando da prolação de sentença. Trata-se de uma das etapas da formação da culpa na investigação criminal, no processo de filtragem apontado por Aury Lopes Jr. ${ }^{18}$

17 ANSELMO, Márcio. Ato do indiciamento deve ser devidamente fundamentado. Disponível em http://www.conjur.com.br/2015-out-13/academia-policia-atoindiciamento-devidamente-fundamentado. Acesso em 05/04/2016.

18 LOPES JR. Aury. Direito Processual Penal. 10ㅉe ed. São Paulo: Saraiva, 2012, p. 280. 
O indiciamento, a peça acusatória e a sentença judicial são reflexos do juízo técnico-jurídico de cada uma das autoridades envolvidas na persecução penal, sendo vedada a interferência nesse processo de formação de convencimento, sob pena de desconstrução do modelo acusatório, o qual sustenta divisões precisas entre as funções de investigar, de acusar e de julgar, a fim de que o Estado atue de forma isenta e imparcial durante toda a persecução penal.

Em consonância com a posição consolidada na Suprema Corte, o Poder Judiciário, em razão do nosso modelo acusatório, deve atuar na fase investigatória somente para inibir violações à ordem legal e constitucional que possam trazer prejuízos às garantias do investigado como sujeito de direito. $\mathrm{O}$ reflexo da estrutura acusatória para a condução do Inquérito Policial é a impossibilidade de o magistrado se imiscuir no campo de discricionariedade do Delegado de Polícia quanto à necessidade, oportunidade e conveniência da realização de diligências investigatórias.

Da mesma forma, os efeitos desse modelo impedem o Poder Judiciário de interferir no convencimento técnico-jurídico externalizado pela autoridade policial no momento em que se indicia um investigado, concluindo-se, após o emprego de variados meios de investigação, pela ocorrência de prática delitiva, diante de fato típico, com materialidade e de indícios de autoria.

Nada impede que vícios de legalidade presentes no despacho de indiciamento, como a ausência de fundamentação ou mesmo inexistência de materialidade ou de indícios de autoria, possam ser analisados a posteriori pelo magistrado, desde que este controle seja exercido com o propósito de garantir a legalidade e constitucionalidade dos atos da autoridade policial. A função jurisdicional, contudo, não pode influir no mérito do indiciamento, no sentido de impor à autoridade policial que se posicione no mesmo sentido de eventual requisição ou autorização 
do magistrado, já que ambas são posturas judiciais incompatíveis com o modelo acusatório adotado em texto constitucional.

O Supremo Tribunal Federal, em decisão recente, firmou entendimento segundo o qual o indiciamento constitui atribuição exclusiva da autoridade policial, de modo que não pode ser requisitado pelo magistrado sob pena de afronta ao princípio acusatório. Eis a ementa da decisão:

Ementa: HABEAS CORPUS. PROCESSUAL PENAL. CRIME CONTRA ORDEM TRIBUTÁRIA. REQUISIÇÃO DE INDICIAMENTO PELO MAGISTRADO APÓS O RECEBIMENTO DENÚNCIA. MEDIDA INCOMPATÍVEL COM O SISTEMA ACUSATÓRIO IMPOSTO PELA CONSTITUIÇÃO DE 1988. INTELIGÊNCIA DA LEI 12.830/2013. CONSTRANGIMENTO ILEGAL CARACTERIZADO. SUPERAÇÃO DO ÓBICE CONSTANTE NA SÚMULA 691. ORDEM CONCEDI$D A$. 1. Sendo o ato de indiciamento de atribuição exclusiva da autoridade policial, não existe fundamento jurídico que autorize o magistrado, após receber a denúncia, requisitar ao Delegado de Polícia o indiciamento de determinada pessoa. A rigor, requisição dessa natureza é incompatível com o sistema acusatório, que impõe a separação orgânica das funções concernentes à persecução penal, de modo a impedir que o juiz adote qualquer postura inerente à função investigatória. Doutrina. Lei 12.830/2013. 2. Ordem concedida. (HC 115015, Relator(a): Min. TEORI ZAVASCKI, Segunda Turma, julgado em 27/08/2013, PROCESSO ELETRÔNICO DJe-179 DIVULG 11-09-2013 PUBLIC 12-09-2013)

Da mesma forma, o indiciamento também não pode ser condicionado à prévia autorização do Poder Judiciário, uma vez que os efeitos dessa conduta também significariam ingerência indevida do Poder Judiciário em questões de natureza manifestamente inquisitorial. Sem delongas, caso autorizado o Delegado de Polícia a proceder ao indiciamento, o magistrado estaria antecipando juízo de valor, afirmando que houve prática delitiva, 
bem como estariam presentes a materialidade e indícios de autoria. Por outro lado, caso denegada a autorização, seu posicionamento já estaria firmado em sentido contrário.

Nas investigações que contemplam investigados com prerrogativa de foro, o tratamento dado ao indiciamento, independente de regramento específico de regimentos internos ou leis esparsas, deve ser idêntico àquele observado nos Inquéritos Policiais em que se verifica a incidência exclusiva do Código de Processo Penal, já que a vedação de interferência do magistrado, quando a autoridade policial realiza um indiciamento, não decorre de atos normativos primários, mas sim de mandamentos constitucionais, os quais estruturam nosso modelo acusatório penal.

O próprio RISTF, no artigo 231, trata da figura do indiciado:

$\S 2^{\circ}$ As diligências complementares não interrompem o prazo para oferecimento de denúncia, se o indiciado estiver preso.

$\S 3^{\underline{0}} \mathrm{Na}$ hipótese do parágrafo anterior, se as diligências forem indispensáveis ao oferecimento da denúncia, o Relator determinará o relaxamento da prisão do indiciado; se não o forem, mandará, depois de oferecida a denúncia, que se realizem em separado, sem prejuízo da prisão e do processo.

Necessário ainda destacar o posicionamento da lavra do Ministro Teori Zavascki, ao apreciar a Pet. 5899-DF, em decisão de 02/03/2016, onde o mesmo reconhece a função do Supremo Tribunal Federal, na fase investigatória, de atuar no controle da legitimidade dos atos e procedimentos de coleta de prova, autorizando ou não medidas submetidas à reserva de jurisdição:

3. Cumpre registrar, por outro lado, que, instaurado o inquérito, não cabe ao Supremo Tribunal Federal interferir na formação da opinio delicti. É de sua atribuição, na fase investigatória, controlar a legitimidade dos atos e procedimentos de coleta de provas, autorizando ou não as medidas persecutórias submetidas à reserva de jurisdição, como, por exemplo, 
as que importam restrição a certos direitos constitucionais fundamentais, como o da inviolabilidade de moradia (CF, art. 5, XI) e das comunicações telefônicas (CF, art. 5, XII). Todavia, o modo como se desdobram as demais atividades investigativas e o juízo sobre a conveniência, a oportunidade ou a necessidade de diligências tendentes à convicção acusatória são atribuições do Procurador-Geral da República (Inq 2.913-AgR, Min. LUIZ FUX, Tribunal Pleno, DJe de 21/6/2012), que, na condição de titular da ação penal, é o "verdadeiro destinatário das diligências executadas" ( $\mathrm{Rcl}$ 17.649 MC, Min. CELSO DE MELLO, DJe de 30/5/2014), bem como da autoridade policial, nos termos do art. 230-C do Regimento Interno do Supremo Tribunal Federal.

4. Definido, assim, o nível de interferência do Poder Judiciário na fase de investigação, registra-se, todavia, ser do mais elevado interesse público e da boa prestação da justiça que a atuação conjunta do Ministério Público e das autoridades policiais se desenvolva de forma harmoniosa, sob métodos, rotinas de trabalho e práticas investigativas adequadas, a serem por eles mesmos definidos, observados os padrões legais, e que visem, acima de qualquer outro objetivo, à busca da verdade a respeito dos fatos investigados, pelo modo mais eficiente e seguro e em tempo mais breve possível. Observadas essas circunstâncias, nada impede a instauração do presente inquérito.

Desse modo, conclui-se que o indiciamento deve ser tratado, mesmo nos inquéritos originários, em conformidade com os ditames do modelo acusatório, do Código de Processo Penal e da Lei $\mathrm{n}^{-}$12.830/2013, já que tanto a Lei n⿳ำ 8.038/90 quanto o Regimento Interno se mostram silentes a respeito deste e de grande parte dos temas pertinentes à investigação criminal.

Isto posto, num estado democrático de direito, a prerrogativa de foro apenas acarreta aos ocupantes dos cargos públicos contemplados o direito de ter como juiz natural, durante a instrução processual, a autoridade judiciária competente, não sendo admissível, sob este pretexto, a subversão da lógica acusatória de 
modo a legitimar a intervenção do Poder Judiciário em questões de natureza manifestamente inquisitorial.

Ademais, nada obsta sequer a aplicação do artigo Art. 17-D da Lei n ${ }^{\circ}$ 9.613/98, que estabelece que "Em caso de indiciamento de servidor público, este será afastado, sem prejuízo de remuneração e demais direitos previstos em lei, até que o juiz competente autorize, em decisão fundamentada, o seu retorno", nos casos de lavagem de dinheiro, já aplicado, a título de exemplo, para ocupante de cargo de prefeito ${ }^{19}$.

Sendo assim, nota-se que o indiciamento nos inquéritos originários independe de prévia autorização ou de requisição judicial, o que não impede nem prejudica a supervisão judicial do Ministro-Relator na sua função de garantidor de direitos fundamentais e de fiscalizador da legalidade da persecução penal. Ao revés, trata-se de construção necessária para compatibilizar o instituto em voga com os ditames constitucionais e legais regentes da investigação criminal.

\section{E QUANTO Às SOLUÇÕES?}

Inicialmente, cabe reforçar aqui o texto constitucional que, no artigo 102, estabelece que compete ao STF a prerrogativa de processar e julgar originariamente. Nada diz a Constituição Federal quanto à investigação. Assim, uma primeira interpretação razoável é admitir-se que a investigação nos casos de crimes praticados por autoridades detentoras de foro por prerrogativa de função se dê de acordo com as regras do Código de Processo Penal e apenas o processo e julgamento se dê perante o tribunal constitucionalmente previsto.

19 Prefeito pernambucano é afastado com base na Lei de Lavagem de Dinheiro. Disponível em http://www.conjur.com.br/2015-out-08/prefeito-afastado-base-leilavagem-dinheiro. Acesso em 05/04/2016. 
Como bem coloca Henrique Hoffman ${ }^{20}$ no artigo já citado: a competência ratione personae não desloca para o tribunal as funções de Polícia Judiciária. A remessa do inquérito policial em curso ao tribunal competente para a eventual ação penal e sua imediata distribuição a um relator não o torna autoridade investigadora, mas apenas the comete as funções ordinariamente conferidas ao juiz de primeiro grau, na fase pré-processual das investigações (STF, HC 82.507, Rel. Min. Sepúlveda Pertence, DJ 10/12/2002; STF, RHC 84.903, Rel. Min. Sepúlveda Pertence, DJ 04/02/2005).

E, mais adiante:

a instauração e inquérito policial para a apuração de fato em que se vislumbre a possibilidade de envolvimento de titular de prerrogativa de foro não depende de iniciativa do chefe do Ministério Público. Tanto a abertura das investigações quanto o eventual indiciamento são atos da autoridade que preside o inquérito, a saber, o delegado de polícia (STF, Pet 3.825 QO, Rel. Min, Sepúlveda Pertence, DJ 11/04/2007).

Nessa linha, passível de implementação a curto prazo, uma vez que não demanda reforma no texto constitucional, trata-se da correção da interpretação equivocada da tramitação dessas investigações envolvendo autoridades com prerrogativa de foro. Em que pese o decidido pelo STF na ADI 1750 no sentido de que o juiz brasileiro não pode investigar crimes, tem havido entendimento no sentido de que, no caso de investigação preliminar relacionada a detentores de prerrogativa de foro (Inq 2963-RR) deve ter tramitação judicial, sob supervisão do relator, conforme Fábio Bechara ${ }^{21}$, que aponta críticas ao entendimento.

20 Henrique Hoffman (http://www.conjur.com.br/2016-mai-17/academia-policiainterpretacao-foro-privilegiado-atrapalha-investigacao-policial).

21 BECHARA, Fabio Ramazzini. Juiz deve controlar legalidade de investigação criminal, não ser protagonista. Disponível em http://www.conjur.com.br/2015-nov-21/fabiobechara-juiz-nao-protagonista-investigacao. Acesso em 27 abr. 2016. 
O tema foi analisado pela Ministra Elen Gracie, em decisão na Pet. 3248-DF, publicada em 23/11/2004, ao decidir que:

Não parece razoável admitir que um ministro do Supremo Tribunal Federal conduza, perante a Corte, um inquérito policial que poderá se transformar em ação penal, de sua relatoria. Não há confundir investigação, de natureza penal, quando envolvido um parlamentar, com aquela que envolve um membro do Poder Judiciário. No caso deste último, havendo indícios da prática de crime, os autos serão remetidos ao Tribunal ou Órgão Especial competente, a fim de que se prossiga a investigação. É o que determina o art. 33, § único da LOMAN. Mas quando se trata de parlamentar federal, a investigação prossegue perante a autoridade policial federal. Apenas a ação penal é que tramita no Supremo Tribunal Federal. Disso resulta que não pode ser atendido o pedido de instauração de inquérito policial originário perante esta Corte. E, por via de conseqüência, a solicitação de indiciamento do parlamentar, ato privativo da autoridade policial.

Ao observar o regimento interno do STF, não se identificam elementos que possam corroborar o entendimento atual no sentido de que a tramitação da investigação preliminar para apuração de infrações penais praticadas por autoridades com prerrogativa de foro perante aquele tribunal devam seguir rito diverso do previsto no Código de Processo Penal.

Necessário novamente destacar o teor do artigo 102 da CF que atribui ao STF a competência para processar e julgar, não se fala em investigar. E mais, tal interpretação não se coaduna com o sistema acusatório, criando verdadeiros juizados de instrução, conforme conclui Danielle Cavalcanti ${ }^{22}$

O fato de ser o tribunal o órgão competente para o processo e o julgamento do agente público não implica admitir-se

22 CAVALCANTI, Danielle Souza de Andrade e Silva. A investigação preliminar nos delitos de competência originária de tribunais. Rio de Janeiro: Lumen Juris, 2011, p. 280. 
a sua titularidade também para a condução da investigação preliminar. A prerrogativa de foro é critério pertinente, de modo exclusivo, à determinação da competência jurisdicional originária do Tribunal respectivo, agindo seja no momento do oferecimento da acusação ou, eventualmente, antes dela, apenas se necessária alguma medida cautelar sujeita à prévia autorização judicial. (...)

No que tange à condução da investigação preliminar, em consonância com sua natureza, os atos ordinários de investigação devem ser praticados pela autoridade policial.

Assim, a fase de investigação preliminar, desde sua instauração, não carece de qualquer autorização da autoridade judiciária, devendo simplesmente submeter-se aos ditames legais.

Eduardo Pereira da Silva ${ }^{23}$, ao tratar do tema pontua que "ao permitir a realização de investigações criminais por seus Ministros (...) o Supremo Tribunal Federal coloca em xeque o sistema acusatório". No mesmo sentido é o entendimento de Rodrigo Carneiro Gomes $^{24}$, para quem "os Tribunais pátrios não devem conduzir investigações criminais, exceção feita na hipótese de fatos relacionados a magistrado que figure na qualidade de investigado".

Ainda nesse sentido, Fábio Bechara ${ }^{25}$, ao tratar desse "inquérito originário", pontua que o mesmo "se traduz numa indesejada ampliação do foro por prerrogativa de função na Constituição Federal, para além do processo e julgamento da ação penal".

23 SILVA, Eduardo Pereira da. Investigação de autoridades deve ser conduzida pela polícia. Disponível em http://www.conjur.com.br/2006-jul-23/investigacao_ autoridades_conduzida_policia. Acesso em 27 abr. 2016.

24 GOMES, Rodrigo Carneiro. O inquérito policial na investigação de parlamentar. Revista Brasileira de Direito Constitucional - RBDC n. 14 - jul./dez. 2009, p. 23.

25 BECHARA, Fabio Ramazzini. Juiz deve controlar legalidade de investigação criminal, não ser protagonista. Disponível em http://www.conjur.com.br/2015-nov-21/fabiobechara-juiz-nao-protagonista-investigacao. Acesso em 27 abr. 2016. 
Em outro aspecto, em que pese não seja diretamente o objeto do presente artigo, mas nos parece importante destacar a necessária revisão do texto constitucional quanto ao extenso rol de autoridades submetidas à prerrogativa de foro no Brasil, que teria sobretudo o efeito colateral de reduzir a sobrecarga dos tribunais superiores.

Como uma das alternativas, em matéria já citada, o Ministro Luis Roberto Barroso ${ }^{26}$ sugere a criação de uma vara federal especializada no Distrito Federal, para julgar os casos que hoje desfrutam de foro privilegiado. O juiz titular seria escolhido pelo STF e teria um mandato de quatro anos, ao final dos quais seria automaticamente promovido para o $2^{\underline{o}}$ grau. Teria tantos juízes auxiliares quantos necessários, mas seria um único titular para dar unidade aos critérios de decisão. De suas sentenças caberia recurso para o STF ou para o STJ, conforme a autoridade.

Opinião semelhante também foi recentemente expressada por Ali Mazloum ${ }^{27}$ que sugere a criação do juizado de autoridades:

Um juizado composto de cerca de 20 juizes federais, arregimentados das cinco regiões do país pelo Superior Tribunal de Justiça, pelo critério único da antiguidade (evitando escolhas subjetivas), instalado na capital federal, poderia com maior celeridade processar e julgar, em colegiados de três juízes, causas penais (até improbidade!) envolvendo ditas autoridades.

Perante esse juizado, atuariam delegados federais e membros do Ministério Público Federal com amplos poderes de investigação, ressalvadas matérias afetas à reserva de jurisdição. O juiz que atuasse na fase investigatória para decidir ques-

26 BARROSO, Luis Roberto. Foro privilegiado deve acabar ou ser limitado aos chefes dos Poderes. Disponível em http://www.conjur.com.br/2016-mai-23/roberto-barrosoforo-privilegiado-acabar-reduzir-impunidade. Acesso em 27 abr. 2016.

27 MAZLOUM, Ali. Uma proposta de criação do Juizado dos Crimes de Autoridades. Disponível em http://www.conjur.com.br/2016-abr-23/ali-mazloum-propostacriacao-juizado-crimes-autoridades. Acesso em 27 abr. 2016. 
tões relacionadas a direitos fundamentais não poderia atuar nas turmas de julgamento (preserva-se, com isso, o requisito da imparcialidade).

Das decisões proferidas no âmbito desse hipotético Juizado dos Crimes de Autoridades, caberia recurso diretamente ao Supremo Tribunal Federal. Devolve-se à suprema corte, de conseguinte, o destino jurídico da autoridade processada. Estariam asseguradas a necessária celeridade na apuração de crimes, a igualdade entre todos e, ainda, o duplo grau de jurisdição. $O$ mesmo modelo poderia ser adotado no âmbito dos estados.

Soluções para o problema existem e, em determinada escala, sequer demandam profundas alterações no texto constitucional, o que dificilmente se alcançará tendo em vista o interesse dos agentes políticos na ineficiência do sistema, que lhes apresenta deveras benéfica conforme fartamente observado empiricamente ao longo dos anos.

\section{Conclusão}

No presente artigo, buscou-se tratar da fase de investigação preliminar nos casos de autoridades detentoras de foro por prerrogativa de função - foro privilegiado.

Entendemos que a expressão "processar e julgar" prevista no texto constitucional em nada justifica a existência dos inquéritos judiciais, instrumentos que contrariam frontalmente o sistema acusatório e tem impacto direto na imparcialidade do julgador, que deve ser chamado a se manifestar apenas na apreciação de medidas sujeitas a reserva de jurisdição.

Veja-se que recentemente se observou até mesmo o ajuizamento de Reclamação (23585-DF), questionando ato privativo da autoridade policial que é o indiciamento, conforme expressa previsão legal. 
Portanto, o que sugerimos aqui são dois pontos de reflexão: o primeiro, diz respeito à necessária revisão do quantum de autoridades detentoras de prerrogativa de foro por prerrogativa de função no Brasil; e, no segundo, a questão da interpretação do texto constitucional no que tange à condução dessas investigações.

Assim, considerando o cenário atual, em que o foro privilegiado tem sido apontado como uma das grandes causas da corrupção política em larga escala, tendo em vista as dificuldades evidenciadas na persecução criminal que dificulta uma resposta estatal a esses crimes, é necessário que se busque a compatibilização do mesmo para que se alcance um verdadeiro estado democrático de direito, sobretudo livre de privilégios sem razão de existir.

\section{REFERÊNCIAS}

ANSELMO, Márcio Adriano. CARDOSO, Duilio Mocelin. Prerrogativa de foro não impede indiciamento pela polícia judiciária. Disponível em http://www.conjur.com.br/2016abr-05/prerrogativa-foro-nao-impede-indiciamentopolicia-judiciaria. Acesso em 30 abr. 2016.

\section{ASSOCIAÇÃO DOS MAGISTRADOS BRASILEIROS. Juízes} contra a corrupção. Diagnóstico do problema da impunidade e possíveis soluções propostas pela AMB. Disponível em http:// www.amb.com.br/portal/docs/noticias/estudo_corrupcao. pdf. Acesso em 27 abr. 2016.

BARROSO, Luis Roberto. Foro privilegiado deve acabar ou ser limitado aos chefes dos Poderes. Disponível em http:// www.conjur.com.br/2016-mai-23/roberto-barroso-foroprivilegiado-acabar-reduzir-impunidade. Acesso em 27 abr. 2016. 
BARROSO, Luis Roberto. Ministro Barroso diz que foro privilegiado é "desastre para o país". Disponível em http:// www.conjur.com.br/2016-mar-31/ministro-barroso-foroprivilegiado-desastre-pais. Acesso em 30 abr. 2016.

BECHARA, Fabio Ramazzini. Juiz deve controlar legalidade de investigação criminal, não ser protagonista. Disponível em http://www.conjur.com.br/2015-nov-21/fabio-becharajuiz-nao-protagonista-investigacao. Acesso em 27 abr. 2016.

CAVALCANTI, Danielle Souza de Andrade e Silva. A investigação preliminar nos delitos de competência originária de tribunais. Rio de Janeiro: Lumen Juris, 2011.

FERRAJOLI, Luigi. Direito e Razão: Teoria do Garantismo Penal. São Paulo: RT, 2002.

GOMES, Rodrigo Carneiro. O inquérito policial na investigação de parlamentar. Revista Brasileira de Direito Constitucional RBDC n. 14 - jul./dez. 2009.

LOPES JR. Aury. Direito Processual Penal. 10ª ed. São Paulo: Saraiva, 2012.

MAZLOUM, Ali. Uma proposta de criação do Juizado dos Crimes de Autoridades. Disponível em http://www.conjur.com. br/2016-abr-23/ali-mazloum-proposta-criacao-juizadocrimes-autoridades. Acesso em 27 abr. 2016.

NICOLLIT , Andre Luiz. Manual de Processo Penal. $3^{3}$ Ed. São Paulo: Elsevier, 2012.

PEREIRA, Eliomar da Silva. Teoria da Investigação Criminal - uma introdução jurídico-científica. Coimbra: Almedina, 2010.

ROSA, Alexandre Morais da. Guia Compacto de Processo Penal conforme a Teoria dos Jogos. Florianópolis: Empório do Direito, 2015. 
SILVA, Eduardo Pereira da. Investigação de autoridades deve ser conduzida pela polícia. Disponível em http://www.conjur. com.br/2006-jul-23/investigacao_autoridades_conduzida_ policia. Acesso em 27 abr. 2016. 